Ferry Bühring

\title{
Demokratische Friedenskonsolidierung
}

Zur Erfassung »des« Demokratieprinzips im Recht der Vereinten Nationen am Beispiel der UN-Praxis in Kambodscha und Osttimor

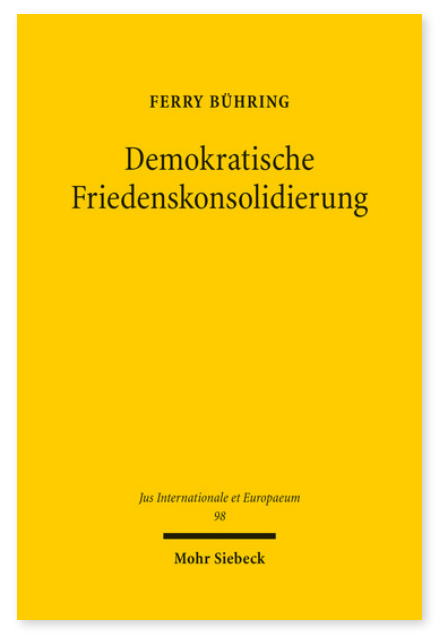

2015. XIX, 372 Seiten. JusIntEu 98

ISBN 978-3-16-153418-8

DOI 10.1628/978-3-16-153418-8

eBook PDF 89,00€

ISBN 978-3-16-153369-3

fadengeheftete Broschur $89,00 €$
Welche Bedeutung hat die Demokratie als Norm des Völkerrechts für das Konzept der Friedenskonsolidierung im System der Vereinten Nationen? Im Unterschied zur gängigen Perspektive, in der die Frage nach der Völkerrechtsnormativität der Demokratie zumeist mit der Zulässigkeit militärischer Interventionen oder nicht-militärischer Sanktionen verknüpft wird, geht es Ferry Bühring um die Konfliktnachsorge. In der Postkonfliktsituation steht das vom Konfliktgeschehen zerrüttete Gemeinwesen typischerweise vor der Herausforderung einer Neugestaltung seiner staatlichen Ordnung. In dieser Nachkonfliktphase kann »das« völkerrechtliche Demokratieprinzip handlungsleitende Wirkungen entfalten. Am Beispiel der UN-Operationen in Kambodscha und Osttimor wird die völkerrechtliche Praxis einer »demokatischen Friedenskonsolidierung « im Sinne eines (Wieder-) Aufbaus bzw. einer Stärkung langfristiger demokratischer Strukturen untersucht.

Ferry Bühring Geboren 1979; Studium der Rechtswissenschaft in Berlin und Amsterdam; Wissenschaftlicher Mitarbeiter am DFG-Sonderforschungsbereich 700 sowie am Institut für Staats-, Verwaltungs- und Völkerrecht an der Freien Universität Berlin; Referendariat am Kammergericht; seit 2013 Rechtsanwalt in Berlin.
Jetzt bestellen:

https://mohrsiebeck.com/buch/demokratische-friedenskonsolidierung-9783161534188?no_cache=1 order@mohrsiebeck.com

Telefon: +49 (0)7071-923-17

Telefax: +49(0)7071-51104 